\title{
The Lyre of King David and the Greeks
}

\section{Citation}

Russell, James 2017. The Lyre of King David and the Greeks. Judaica Petropolitana 8.

\section{Published Version}

http://judaica-petropolitana. philosophy.spbu.ru/Archive/issue.aspx?isid=5\&lang=en

\section{Permanent link}

http://nrs.harvard.edu/urn-3:HUL.InstRepos:37143010

\section{Terms of Use}

This article was downloaded from Harvard University's DASH repository, and is made available under the terms and conditions applicable to Other Posted Material, as set forth at http:// nrs.harvard.edu/urn-3:HUL.InstRepos:dash.current.terms-of-use\#LAA

\section{Share Your Story}

The Harvard community has made this article openly available.

Please share how this access benefits you. Submit a story.

\section{Accessibility}




\title{
The Lyre of King David and the Greeks.
}

\author{
By James R. Russell, \\ Harvard University and the Hebrew University of Jerusalem, Israel.
}

Thrown like a star in my vast sleep

I opened my eyes to take a peek

To find that I was by the sea

Gazing with tranquility:

'Twas then when the Hurdy Gurdy Man

Came singing songs of love.

Unenlightened shadows cast

Down through all eternity

The crying of humanity-

'Tis then when the Hurdy Gurdy Man

Comes singing songs of love.

- Donovan Leitch (Scottish musician, 1968)

Greeks listened to, and learnt to play, live music, especially that of the lyre: it was central to their life and culture in a way that is rather unfamiliar to the everyday experience of a person in the present digitalized culture and consequently hard to appreciate, so to understand its importance requires special stress. The instrument figures prominently, given its ubiquity, in religious imagery and cosmological theory. The Greek lyre was loud enough in various ways to be heard across the Aegean as part of the Hellenic cultural and philosophical challenge that Israel encountered, pondered, and answered. In a story that was passed down to Hellenistic and later Persian romance- thus enjoying a very wide currency over considerably more than a millennium- Hermes heard the wind playing through the sinews of a dead tortoise and producing music; he enjoyed the tune of what we would now call an Aeolian harp, but was sad because he could not reproduce it. Later a mysterious old man he just happened to meet by the roadside (though nothing just happens in a folk tale or myth, least of all wise old men in the middle of nowhere) helped him to fashion an instrument he could play by himself. The lyre was born.

In the Iranian version of the tale, the name of Hermes is given as Hurmuz, which just happens (though as we noted above, nothing just happens) to be a form of the name of Ahura Mazda, the good creator God of the Zoroastrians. The old man is given the name Hazhraman: whatever this might also have rendered, it sounds like the name in Middle and New Persian of Ahura Mazda's cosmic enemy Angra Mainyu, Ahriman. So the mysterious elder might be an incarnation of the evil demon. If so, the story can be seen to adumbrate the contrast between the inspired music of the divine, passively received but pure, and active human artifice, which is fallible and 
can be perverted to employ music for the purposes of vice. As a corollary matter, the ancients pondered the states of sleeping, with its passivity, and waking, with its conscious activity.

The pagan figure of Orpheus, the good shepherd and lyre-player who charmed wild animals by his art and brought his wife back from Hades, was co-opted by Judaism and Christianity to the iconography of David, the lyre player who soothed the madness of king Saul and composed the Psalms, and (as the Christian New Testament insists) of David's lineal and messianic descendant Jesus. The possible "Jewish-Christian" Odes of Solomon receive the mixed pagan and Biblical tradition and juxtapose the music of the Aeolian harp with that of the lyre of the poet, the singer of God's praises. The Babylonian Talmud and Midrash Tanchuma contain slightly different versions of a myth about king David rising from a habitually light sleep every midnight when the north wind blew through the lyre hanging above his bed. I suggest that this may be a reply to the Greek aetiological story, and that it was composed so as to assert in multiple ways the pre-eminence of the sweet singer of Israel, by virtue of his true faith, over the siren songs of Hellenism.

\section{Hermes, the turtle, and the devil's music.}

On his day of birth, the Greek god Hermes was on the way to steal the cattle ${ }^{1}$ of his brother, the god Apollo, when he discovered a turtle. He killed it, scooped out its shell, and fashioned a lyre of seven strings. Later on the busy youngster sang to Apollo and gave him the lyre to appease him for the theft. This account, from the Homeric Hymns, $c a .6^{\text {th }}-5^{\text {th }}$ cent. BCE, is the earliest of a number of accounts, which differ in small details, of the complex myth on the origin of the lyre. Lucian, for example, relieves Hermes of the disturbing detail of killing the creature: the little tortoise is already dead when he finds it. ${ }^{2}$ There is a slightly different myth as well, fragmentarily attested in Greek in the Hellenistic romance Metiokhos and Parthenope, ca. $1^{\text {st }}$ cent. BCE; it seems to have become very popular and enduring, for it is more fully related in the Persian romance in mathnavi verse Vāmiq u 'Adhrā of Abu'l Qāsim 'Unsuri (ca.970-ca.1040 CE). The Persian tale relates that the diners at a symposium (dinner party) at the court of Polycrates of Samos (the names are fairly faithfully rendered in Persian transliteration) were discussing the shapes of

\footnotetext{
${ }^{1}$ This is not necessarily an anomalous activity for a mythological figure, though it is admittedly not the first thing human newborns do. Cattle raiding is part of the job description of rakish young IndoEuropean epic heroes and divinities, from Cuchulain in pagan Ireland to the Kalaša god of raiders and rustlers Gī̌s (<gāv-išti- "cow seeking") in the Hindu Kush. The narrative of the Gathas of Zarathustra, in their canonical order, begins with the complaint of the Soul of the Cow against the violence of her kidnappers; and the ancient Iranian Prophet comes in part to preach a way of life that excludes this customary practice as immoral. The raiders were called mairya, a word that originally meant simply "marriageable young man" (and became that again in Middle Persian, as mērag). The young Indian god Krishna enjoys dalliances with the gōpiss, "cowgirls". In America all this is sublimated into the cinematic Western saga.

${ }^{2}$ See Graves 1957, pp. 63-64, for a useful and lively composite summary of the story.
} 
Eros (the god of love). The poet Ibycus took up the barbat ${ }^{3}$ and sang of the beauty of the young couple Vamiq and Adhra, who were present at the celebration. Vamiq then told this story: the farzāna ("wise man") Hurmuz (i.e., Hermes) once went up a mountain to worship God and saw a tortoise (Persian sang-pušt, lit. "rocky-back") with dried sinews. He hung it up and the wind blew through the sinews, making music. Hurmuz wanted then to fashion an instrument he might play by himself, but all his attempts were unsuccessful. He went for a walk down the road feeling bad, and came upon an old man who just happened to be sitting there.

The old man, whose name was Hažrahman, arranged the tortoise shell with strings "in the likeness of the disposition of animate nature" (ämīzeš-i gōhar-i jānvar): "a stroke on the strings is like a movement in our body," he explained. And that was the lyre. The Greek romance was evidently widely popular in the early Islamic period: Ibn al-Nadīm mentions in his Fihrist (the "List" (of the books in his father's Baghdād book shop)) an Arabic translation; and Birūnī knew a Persian prose version. The Persian rendering here of Hermes- Hurmuz- coincides with one form of the name of the good Creator God of Zoroastrianism, Ahura Mazdā, Middle Persian Ohrmazd. This can scarcely have been mere happenstance, and the Iranist Bo Utas suggested reasonably that at some point the coincidence offered an opportunity to make a point. The old man's unusual name, Hazhraman, might be a scribal corruption or, better, an otherwise unattested form of the name Ahreman, the Middle Persian form of Avestan Angra Mainyu - the name of the Evil Spirit, Ahura Mazda's co-eternal cosmic enemy. And Utas remarks, "even if sung for the highest purposes, poetry and music will need something devilish." ${ }^{4}$ Hägg noted that Longus and Achilles Tatius attributed to Pan - the god of the "panic", whom Christians early equated with the devil - the invention of the syrinx, a flute. ${ }^{5}$ Though the woodland god did this in a grief-stricken attempt to reconstruct the sundered limbs of his beloved, might the association of Pan and instrument also have perhaps inspired a transmitter of the tale along the way to 'Unsuri to take up the theme of music as potentially demonic? ${ }^{6}$

There are two kinds of lyre in this story, and the physical distinction between them seems to imply, or to facilitate, a moral divergence of greater import. For the first one, which Hermes makes in one version of the myth but simply discovers in the other version - the one that is attested in the Hellenistic romance and is transmitted down to classical Persian - is the kind of lyre that makes music when when the wind blows through the sinews and makes them vibrate, without the exercise of any human agency save hanging the tortoise shell in the right place for the breezes to find it. This one belongs to God or Nature, without human

\footnotetext{
3 This instrument could be a lyre with deep pitch corresponding to the Greek barbitos, the invention of which was attributed to Terpander of Lesbos ( $7^{\text {th }}$ cent. BCE): see Hägg 1989, p. 47.

${ }^{4}$ See Utas 1997.

5 Hägg 1989, pp. 67-68.

${ }^{6}$ American folklore abounds in cautionary tales about "the devil's music", fiddlers' duels, etc. One need only recall the deal the great bluesman Robert Johnson is supposed to have made with Satan at the proverbial crossroads.
} 
interference. This instrument, which can be manufactured to have the wind play it, is the Aeolian harp; ${ }^{7}$ and it will be of importance to our discussion shortly also to note that in a number of Semitic languages, including Hebrew and Aramaic/Syriac, the word for wind and spirit is the same, Heb. rūah, Syr. rūḥa. So this first kind of lyre produces literally the music of the spirit. The second is the lyre the old man Hazhraman crafted, a work of secondary human artifice ${ }^{8}$ rather than of primary nature $a b$ initio, and one whose strings a musician must willfully strike with a plectrum or pluck with his fingers. Perhaps the intrusion of these elements of individual human artifice and art, of the musical expression of our fallible free will, is what is perceived to open the door to sin and evil- to the devil's music. This problem, or distinction, will loom large in our discussion presently. For the greatest and most vividly portrayed of the kings of Israel, David, made his contribution to Scripture, and to the prayer and music of all later ages, as a lyric poet and musician. How can his art be set apart from that of other players of the lyre? Is it in any way morally vulnerable?

Though until Thomas Edison, a scant century and a half ago, all music was live, technology has set much of humanity at a distance from many of the direct experiences that our ancestors enjoyed and suffered. It is as though the information age and digital recording have thrust us deeper into Plato's cave- farther away from authenticity than ever, and deeper into the dreams of semblance, of illusion and simulacrum. ${ }^{9}$ So the modern reader is unlikely to encounter a harp, much less a lyre, in the course of a day; and most of the music he hears is likely to have been recorded. His experience is thus third-hand, and the instrument is wholly unfamiliar, as are the mechanics and principles of its operation. This engenders a myopia that prevents one from appreciating, unless it is specially emphasized, a point crucial to this discussion: how very important and familiar the lyre is likely to have been for the ancient writers whose mythological tales and philosophical arguments we are presently to consider. All the music of antiquity was live, and the music of the lyre in particular pervaded the culture of ancient Greece. One need think only of the very designation of the genre of lyric poetry to appreciate this, but the lyre had a role in heroic poetry as well, and in the lives of the heroes themselves.

\footnotetext{
${ }^{7}$ It is still manufactured; and the ceaseless winds of the Pacific play with their invisible fingers on the strings of one that hangs at one of the piers at Fisherman's Wharf on the San Francisco Bay, to the distant accompaniment of the hearty barking chorus of the antic congregation of California sea lions at Pier 39.

${ }^{8}$ The Zoroastrians, relevantly for this story, distinguish between the capability of Ahura Mazda to create ex nihilo, expressed by Persian dādan, and Ahreman's more limited ability only to slap things together secondhand (kirrēnīdan) from material already created by God. See Russell 2004, "Some Iranica in Eznik," pp. 1333-1345.

${ }^{9}$ The advertisement for an American sound recording tape used to ask, "Is it real or is it Memorex?" This writer's friend Robert L. Karash, a mystic and computer scientist of genius, used to smile when we enjoyed together one or another direct experience of music or religious practice and say, "It's not Memorex-it's real!" The American science fiction writer Philip K. Dick, on whose work the film "Blade Runner" (1982) was based, explored through a creative life that produced over forty novels the question of cybernetic and other simulacra and its resonance with larger social moral, and ontological issues of identity, human rights, and consciousness.
} 
Reciters of Homer often played the lyre (Greek kithara or kitharis; the synonymous term lyrā is first attested in the poetry of Archilochus of Paros, $7^{\text {th }}$ cent. BCE); and according to Homer both the Achaean warrior Achilles ${ }^{10}$ and the Trojan prince Paris were accomplished players of the instrument. Aeschylus (Supp. 681) called the grimness of war in which the former at least excelled "lyre-less, generating tears"; so when the best of the Achaeans plays, it is in the lulls between battles, underscoring thereby, perhaps, their very horror. Musical training was a basic part of education for life, and Greeks could not imagine a paradise after death without it, either: Pindar includes the music of the lyre among the pleasures of the city of the virtuous departed (Pyth. 10.37f.). Music, with lyres and pipes, was associated mostly with cheerful events - with such celebrations as weddings or symposia- but also with ritual processions, both joyful and solemn. There were lyres of different types, as well as harps; and a red-figure Attic pottery fragment depicts young men playing tortoise-shell lyres (chelys) ${ }^{11}$ — the kind Hermes was said to have invented. ${ }^{12}$ Music, being so ubiquitous and so obviously mathematical in its principles, was a subject of physical investigation and of cosmological, philosophical, and spiritual speculation. The Pythagorean school, followed by Plato, conceived the idea that the measurable, arithmetical intervals of the harmonies of terrestrial music pervaded the cosmos, with the sounds and distances of the paths and movements of the heavenly bodies of the rational macrocosm corresponding - resonating, literally - to those of the soul, thoughts, passions, and bodily members of the human being, the microcosm. For one recalls also that the Greeks believed the sound of each string of Hermes' lyre did not merely stir the spirit - it resounded to a specific member of the human body.

2. The lyre and the philosophers.

The practice of philosophy, being the loftiest discipline of the mind, might thus lead one to appreciate the best of music and to experience the correspondingly highest music of the spheres; while the appropriate kinds of music performed here on earth were believed to have the power to exert a psychological influence upon an individual, with therapeutic effect. Doctors employed music in the belief it might heal both maladies of the soul and physical diseases. Of course not all music could do this: if some was sublime, other sorts might serve only to excite the lower passions (in latter-day terms, this would be the "sex and drugs and rock 'n roll" kind), and to do harm. In the Republic, Plato prescribes limiting the kind of music that the youth of his imagined, metaphorical polis are allowed to hear, preferring military music to other types as being most encouraging to patriotic sentiment and

\footnotetext{
10 A Syrian mosaic inscribed in Estrangela, mid-to-late $3^{\text {rd }}$ cent. CE, in the Bible Lands Museum, Jerusalem, Israel, shows Achilles ('klws) with a lyre serenading Patroclus (ptrqls). The two are seated on a low couch together: Achilles holds the lyre upright in his left hand and extends his right hand to his beloved friend; Patroclus gestures with his left hand towards Achilles, and holds a leafy branch in his right. See Russell 2001-2002, p. 62 pl. 9.

${ }^{11} \mathrm{Cf}$. the ancient Roman riddle Dum vixi tacui; mortua, cano ("I was silent when alive; havind died, I sing"), the answer to which is Greek khelōne, "tortoise".

12 See West 1992, pp. 13-15, 50, and Pl. 18.
} 
conducive to useful activity. ${ }^{13}$ Aristotle categorized the functions of music as educative (paideia), as providing intellectual enjoyment (diagōgē), and as effecting purification (katharsis). The Neoplatonist Plotinus, who viewed all things as linked in a chain of being, emanating from higher to lower, classified music in a three-stage hierarchy: mousikos, erōtikos - and, of course, philosophical. Christians inherited much of this ancient pagan music theory: some kinds of music might be base, and to be avoided; so some churches to this day disdain polyphony and the playing of instruments, preferring plain song. But in its highest form music was angelic song: the Trisagion (Greek, "Thrice Holy", corresponding to the Hebrew Qedushah) chanted before the throne of God, and conveyed to the prophet Isaiah by an angel. ${ }^{14}$

The lyre enjoyed a potent association with Greek religious mythology that went beyond mere theories of cosmology, psychology, and philosophy and entered the realm of faith and of hopes beyond the grave. It was the instrument of Orpheus: when he played his lyre, birds and wild animals listened attentively and became tame, rivers paused in their flow, and even rocks and trees edged down the mountain sides to be closer to the mystic musician. As a shipmate of the Argonauts, Orpheus was able to out-perform the songs of the Sirens; and by his music he prevailed upon Hades to release his wife Eurydice. The music of Orpheus so entranced the men of Thrace that their wives conspired to relieve him of his headwhich, though severed, seemed to survive death, for it kept on singing. A lost Orphic book referred to by Varro explained that the seven strings of the lyre of Orpheus corresponded to the seven circles of heaven; the souls thus required the strains of the kithara to make their ascent. (Eratosthenes wrote in a poem that Hermes himself went up to heaven and marveled to find the planets humming along their paths on the very notes of the lyre that he had invented down on earth.) So the theory of correspondences was widened to embrace the belief in the soul's ascent after death, psychanōdia. It is not clear that there was in antiquity a definably Orphic religion, but it is undeniable that there existed a complex of mystical beliefs about

\footnotetext{
13 Platonic strictures about music have had an enduring influence on the cultural policy of ideologydriven societies, far beyond Christian fundamentalism. The Beatles were banned in the early 1960s from playing in the State of Israel for fear their songs might turn the longings of young kibbutzniks from their tractors to girls. Russian readers will recall that a similar anxiety animated the ideologues of culture of the Soviet Union, who denied that there was such a thing as "sex" in the workers' paradise at all - a very chaste Eden. As the Soviet bard Vladimir Vysotsky sang in his satirical "Instructions before a trip abroad", Там шпиёнки с крепким телом:/ Ты их в дверь - они в окно!/ Говори, что с этим делом/ Мы покончили давно. "There are girl spies out there with supple bodies:/ Show them the door and they come in through the window!/ Well, just explain it to them straight:/ We put an end to all that business long ago." Ever since Karl Popper's The Open Society and Its Enemies, the notion has lodged firmly in Western thinking that Plato advocated artistic censorship, as part of the recipe for a totalitarian society of the kind that modern man knows, unhappily, only too well. But this idée reçue is untrue: in the dialogue, Socrates takes pains repeatedly to emphasize that his politeia is but a convenient metaphor for the study of the parts of the soul and of its training and control, and not a prescription or suggestion for the organization, governance, and morals of an actual human polity.

14 Wellesz 1998, p. $49 f$.
} 
salvation from death and other mysteries, expressed in hymns that focused on the divinized human singer. ${ }^{15}$

The figure of Orpheus as a spiritual master of the lyre posed a challenge to Jews at a fairly early date, and they found a creative solution: in the second century BCE, Aristobulus of Alexandria in his commentary on the Pentateuch identified Moses with the Greek Musaeus, making the latter the teacher of Orpheus, thereby subordinating the Greek sage, songster, and shaman to the greatest of men, the lawgiver of Israel, who spoke with God awake and face to face (more on Moses and David presently). And in a pseudepigraphon, Orpheus is made to abandon his inconvenient polytheism for belief in the one true God. The loose ends are neatly tied $^{16}$ Early Christians adopted as a matter of course various images of earlier gods and philosophers to portray their Savior. Among these was the figure of Orpheus and his lyre (or with a little lamb), employed to depict Christ the good shepherd; and the episode of Orpheus and Eurydice was taken as an obvious foreshadowing of Christ's own harrowing of hell and liberation of the souls of the righteous. ${ }^{17}$ But Christ was not to the best of our knowledge a musician. The pre-eminent harpist of the Bible is King David; so that musical aspect of Orpheus was diverted to the Psalmist. Medieval Christian commentators compared the healing strains of Orpheus' lyre to the young David's exorcism by his lyre playing of the demon from the afflicted King Saul. The image of Orpheus picking his lyre and charming the animals also found new employment in the iconography of King David, among both Christians and Jews. ${ }^{18}$

Christians inherited from the Hebrew Bible the Book of Psalms, which from the start came to play just as important a role in the evolving liturgy of the new faith as

15 West 1983, pp. 4, 30-31.

16 West 1983, pp. 33-34.

17 See Boardman 1970, especially chapters II and III: "Moses' Pupil: The Orpheus Who Came out of Egypt" and "Orpheus-Christus in the Art of Late Antiquity", pp. 13-85; and Mathews 1993. The latter argues specifically against the so-called "imperial" image of Christ that seems to have been particularly popular with German scholars, in favor of more eirenic and less political models. Christians tended to regard the pagan gods, heroes, and mythological themes that had affinities to their own divinities and beliefs as either phenomena prefiguring the revelation of the full truth, or (as in the case of recorded miracles in paganism) as demonic simulacra designed to lure men away from genuine, true religion - the latter being the case especially with regard to Mithraism, which never posed a real challenge to Christianity but was still seen as uncomfortably and threateningly similar, with its rites and mysteries and soteriological doctrines.

18 Boardman 1970, pp. 149-155: see especially Pl. 19 opp. p. 151, in which the crowned King David, seated in the shade of the letter reš of the Hebrew word Ašrei ("Happy is the man who has not walked in the counsel of the wicked...") at the beginning of the Book of Psalms, serenades with a harp four animals in niches above the incipit (Ambrosiana B., 32 inf., 3r, $13^{\text {th }}$ cent.). David is also shown (and named, in scripta plena Hebrew as $d w y d$ ) on a mosaic from a synagogue of the early Byzantine period at Gaza, Israel: he is seated, playing a multi-stringed lyre with a little hammer, and various wild animals including a giraffe are gamboling tamely before him. The image, clearly derived from that of Orpheus, has achieved modern iconic status: it is reproduced, for instance, without the exotic animal audience, on a medal of the State of Israel commemorating the $3000^{\text {th }}$ anniversary of Jerusalem, City of David. 
it did and still does in Israel. But there is an interesting disparity in nomenclature: the name of the Biblical book in Greek, which was duly inherited by Slavonic, English, and most other Christianate languages, means literally music sung to the plucking of the strings of a lyre - that of King David. But in Hebrew the "Psalter" has no such designation, no such specific focus on the instrument. It is Sēfer Tehillim, literally the Book of Praises, from the unique superscription of Psalm 145, Tehillāh le-Dāvid. (No other Psalm bears this title.) The Syriac term for the Psalter, ktāba $d$ mazmūre, lit. "book of songs/melodies", cf. the Hebrew superscription of some Psalms le-Dāvid mizmōr - seems to occupy a middle ground between music and praise. It is musical and not just words, but musical also without necessary reference to a lyre, though, as we shall observe presently, that instrument is exceedingly prominent in Syriac Christian poetic imagery.

The first lyre known to history is depicted in a pavement graffito of ca. 3100 BCE from Tel Megiddo, Israel. ${ }^{19}$ That does not mean it was invented right there in the Holy Land (or that it is to provide musical accompaniment to the end of the world at Armageddon!), but it is at least strong evidence for the Near Eastern origin of the instrument. We do not know what the anonymous artist called the object he had doodled, but the usual term for it in Biblical and later Hebrew is kinnōr, loaned for instance into Armenian via Syriac kenār as k'nar. (The Psalter mentions many different musical instruments, including harps and lyres with different numbers of strings. The nevvel, for instance, had 22, said to correspond to the number of letters in the Hebrew alphabet. ${ }^{20}$ ) There is a Cycladic marble statue from the island of Keros, somewhat later, from the $3^{\text {rd }}$ millennium BCE, of a seated harpist playing his instrument, and "some sort of seven-stringed lyre" is represented by a Minoan hieroglyph. The lyre probably came to Crete and mainland Greece from the Near East: so its origins go back to the beginnings of civilization and it seems quickly to have achieved universal popularity in the ancient world. ${ }^{21}$ But it is to the preeminent player of the lyre in the Near East, in Biblical tradition, that we now turn.

\section{The sweet singer of Israel.}

The singer and lyre-player par excellence of ancient Israel was of course King David, the comely, ruddy young shepherd whose playing soothed King Saul in his madness. Orthodox Jews attribute the Psalms to some ten different authors, beginning with Adam; and secular scholarship considers them to belong to different hands and ages, for quite different reasons. Perhaps the point is not so much as to argue fruitlessly over which of the songs belong to David as to observe why the most poetic book of the Bible is called his own. He is the most poetic of Biblical figures. The very name David means "beloved", and as one recent biographer has observed,

\footnotetext{
19 West 1992, p. 49.

${ }^{20}$ Following the theory of corresponding resonances harmonizing members of the body and sounds, this likening of the 22 strings to the 22 letters would be but one more facet of the magical employment of the alphabet. In pagan Greco-Roman and later Christian societies, special powers and influences, Divine and other, were assigned particularly to the seven vowels. See Russell 1989.

${ }^{21}$ Lindsay 1968, pp. 14, 115, and plate opposite p. 29.
} 
nobody in the Bible is loved so often, as much, or by so many as he. ${ }^{22}$ Lyric verse is often the poetry of love, but seldom does it celebrate the lineaments of gratified desire; and all David's love relationships are beset by problems, tragedies, and reversals. The ruddy, handsome young shepherd, delicate and gentle, was also the diminutive warrior who slew Goliath and created in that instant one of the most durable archetypes of the human imagination - that of the underdog defeating the seemingly invincible juggernaut of the oppressor. David the king was the charismatic who leaped and danced stark naked before the Ark, to the prudish lady Michal's consternation. ${ }^{23} \mathrm{He}$ is a complex, even a tragic figure, allowed to make Jerusalem the royal capital, the site of the House of God (so Rabbinic doctrine still assigns him the credit of a builder), but forbidden by God to erect the Temple therein. That is left to his son, Solomon. For David lusted after Bathsheba and arranged for the death of her husband, provoking the wrathful, sarcastic accusation by Nathan: You have murdered, and you would inherit? It may be the earliest case of the condemnation of chutzpah in world literature. Yet in his own last words, in 2 Samuel 1-2, David declares, appropriately in song, his vindication: Ne'um Dāvid ben Yišai ū-ne'um hag-gever huqam 'āl, mešīaḥ Elohēi Ya'aqov ū-ne'īm zmīrōt Yiśrāèl:/ Rūah YHWH dibber bī, ū-millātō 'al lešōnī. "David son of Jesse speaks, yea, the man established on high speaks - the anointed of the God of Jacob and the sweet singer of Israel:/ The spirit of the Lord has spoken through me, and His word is upon my tongue." The image here of the spirit of the Lord (it is again to be recalled that "spirit" and "wind" in Hebrew are the same word) speaking in or through David, the harpist, might conjure up in the imagination of a reader of the Hellenistic period and Late Antiquity the evidently well known aetiological myth, discussed above, of the wind/spirit passing through the sinew-strings of the tortoise-shell Aeolian harp of Hermes. Thus David, though the human player of the lyre, may be absolved from the danger of playing on his own and making Ahreman's music, as it were, since he is no less than the inspired anointed of God: the wind of Heaven blows through him.

A hymn composed in the early Christian centuries takes the two images: Hermes' tortoise-shell lyre and the Divine spirit/wind speaking through David- and sets them side by side, with a little mystical music theory added on about the resonances of the strings to the parts of the body. The mention of love at the end of the pericope perhaps is an oblique nod to the king whose very name means love. Thus, the first two verses of the sixth of the Syriac Odes of Solomon read: (1) Ayk da-mehalkā (rūhāa) b-qītārā u-menne memallān (2) hākanā memallāl b-handāmai rūḥeh d-māryā wamemallel 'nā be-hübeh. "As the wind/spirit grows through the kithara and the strings speak,/ So speaks in my limbs/members ${ }^{24}$ the spirit of the Lord and I speak in His love." The hymn continues: He destroys all that is alien forever, and nothing shall oppose Him. He multiplied knowledge and gave us His praise. Then a stream

\footnotetext{
22 Wolpe 2014, p. x.

${ }^{23}$ One scholar has argued that a naked dancing figure carved in the center of a round marble slab a little over half a meter wide - perhaps the top of a little side table - of the Roman Imperial period is David and the object is Jewish. The object was unearthed in the province of Pannonia (modern Hungary). See Thomas 1970.

${ }^{24}$ In Syriac this is a loan from Middle Iranian handām, cf. Armenian andam "member".
} 
came from Him and widened into a river that carried all away and brought it to the Temple (l-hayklä, cf. Hebrew heikhal). ${ }^{25}$ Nothing could restrain the stream, it spread everywhere, and all the thirsty drank of it. Happy or blessed (țūbayhūn, lit., "it is good for them": this is the Syriac term that consistently renders the Hebrew ašrei of the Psalms, which in turn is the Gk. makarioi of the Beatitudes in the Sermon on the Mount) are its ministers. For the water is restorative, and all lived "by the living water that is for eternity, Halleluyah" (mayyā hayye da-l-ālam, hallelüya).

The original of the Odes was probably Greek. Some of the Odes survive in Coptic, but the Syriac version is by far the most complete. We do not know who composed the Odes or what if any defined religion they belonged to: some earlier scholars associated them with Bardaișan of Edessa; others, with early Christian sectarians. It is not unreasonable to speculate that early Christians who still adhered to some of the mitzvot - such as Sabbath observance, the dietary laws of kashrut, and perhaps male circumcision - and persisted in traditional Jewish reverence for Jerusalem and the Temple might have composed the Odes in Greek, and like-minded people in northern Mesopotamia where Syriac was spoken (Edessa or Nisibis, perhaps) received and welcomed them and subsequently produced a Syriac version for the communal use of local believers who knew no Greek, only the local dialect of Aramaic, Syriac. The Ode cited is in any case sufficient proof that in the age and region of the setting down in writing of the Gemara, a learned religious poet writing also in a form of Aramaic, and not far away, associated David with the Greek myth.

The image, or better, images of lyre and spirit endured and developed in Syriac Pauline Christianity. The great poet-theologian St. Ephrem is regularly called kenārā $d$-rūḥa $d$-qūdša, "the lyre of the Holy Spirit" (or simply, in modern Syriac parlance, Kenoro). The title is still used of St. Narsai as well, but it is pre-eminently Ephrem's. The lyre was evidently seen as superior to the flute: Jacob of Sarug is normally called the "Flute of the Holy Spirit," a designation symbolizing his subordinate position relative to St. Ephrem. Examples of Ephrem's use of the image include the following

25 This is directional, not accusative: see Charlesworth 1973, p. 31 n. 12. Lattke 2009, p. 74, agrees, and further notes that this word for the Temple, he khalä, is a hapax in the text. That would be an argument for specificity - for the author referring to the Temple at Jerusalem. But Lattke states also (p. 81) that the "mythos" of the hymn takes place "in some undefined and timeless past" so there is no point in talking about the Second Temple. Elsewhere he claims, likewise without proof, that the assertion in another Ode that God will never change His holy place for another can have nothing to do with Jerusalem (His holy place). But in context it would seem to have everything to do with the cityperhaps it was a defiant Jewish Christian response to the Pauline Christians' abandonment of earlier reverence for the city and Temple following its destruction of $70 \mathrm{CE}$ and the further devastation following the defeat of the Bar Kokhba uprising in 135. This context - Lattke's seeming inclination to de-Judaize the Odes and to do so by employing special pleading to neutralize inconvenient evidence to the contrary - raises one's suspicions when he quotes approvingly the question of R.H. Connolly, "Why is the Greek word for harp always used in the Syriac version, and the Semitic word avoided?" Surely the correct answer, if the question is taken as an ingenuous one, would have to include the reflection that the Syriac is a translation of a Greek original. Do the classical Armenian Christian usages of $k^{\prime}$ nar (lyre), $k^{\prime} a h a n a y$ (priest), bèm (altar), sop'r (text), magałat' (parchment), etc., not to mention Amen and Halleluyah, suggest then a de-Aryanizing, a deliberate avoidance of IndoGermanisch? 
passages from his hymns: "Because thou hast loved the poverty, of thy master who in secret was rich, the fountain of his words shall flow from thee, that you may become a harp for the Spirit, and may sing to yourself inwardly His good will;" and "They scorned the trumpet of Isaiah, which sounded forth His pure Conceptionthey silenced the lute of the Psalms, which sang of His Priesthood-the harp of the Spirit [when used of a person by St. Ephrem, this phrase refers exclusively to King David] they hushed, which sang again of His Kingdom - under deep silence they closed up, the great Birth that joined the cry - of them above with them below." 26

When the spirit wafts through a man and stirs the strings of his mind, is he fully conscious, fully in control of his will? Or is he a passive instrument, like the tortoise shell hanging from its perch? Is a person the same when he is asleep as when he is awake? The question, albeit an ancient one, ${ }^{27}$ seems to have exercised the imagination of the heresiarch Montanus, whose teachings have been held to have affinities to Jewish Christianity. ${ }^{28}$ Epiphanius, Haer. 48.4 reports: Montanos phēsin: idou, ho anthrōpos hōsei lyra, k'agō ephiptamai hōsei plēktron. Ho anthrōpos koimatai, k'agō grēgorō. "Montanus says: look, man is just like a lyre, and I [God] fly over like a plectrum. The man lies asleep, and I am awake." ${ }^{29}$ Does the Lord ever sleep? Though "the Guardian of Israel will neither slumber nor sleep" (Ps. 121.4), the question of sleep and waking seems to have been posed even with relation to God, though here it seems more a matter of rousing God and getting the Lord to focus on us down here, rather than speculating about where His mind goes. According to the Mishnah, the High Priest Jonathan abrogated three practices that had been customary in the Temple at Jerusalem. Among them, he abolished the "Awakeners", that is, those who recited "Awake, why do you sleep, 0 Lord" (Ps. $44.24)$ to arouse God in the morning. The idea is not altogether counter-intuitive: even though on a theoretical level the religious believer knows God is aware of everything we do, ${ }^{30}$ one still invites or tries to attract His attention in prayer. Saul Lieberman compared the practice to the way Egyptians used to wake up their god at the Serapeum every morning (as reported by Porphyrius of Tyre). ${ }^{31}$ We shall consider shortly the thoughts of the sages of the Babylonian Talmud on this matter of harps, sleeping, and waking.

\footnotetext{
${ }^{26}$ For this information, including citations, I am indebted to my learned Harvard pupil and friend Mr. Christian Šidak, a devout Syriac Christian fluent in both classical and modern forms of the language.

27 In the play of Sophocles, Oedipus Tyrannus, Jocasta tells Oedipus not to worry about prophecies of incest, since people in dreams marry their mothers. In dreams, the Irish poet William Butler Yeats responded two and a half millennia later, begin responsibilities; and with an extra Freudian urgency the American Jew Delmore Schwartz took up Yeats' statement in a poem and a short story T.S. Eliot acclaimed as a classic.

28 See Ford 1966.

${ }^{29}$ Cited by Lattke 2009, p. 77 n. 28.

30 The tenth of the thirteen articles of faith formulated by Maimonides is expressed in this way in most orthodox prayer books: "I believe with perfect faith that the Creator, may His Name be blessed, knows every deed of the children of Adam and all their thoughts. As is said, He shapes their hearts together and understands all their deeds."

31 See Lieberman 1950, p. 142.
} 
We are to consider presently a story about how David used to hang his lyre on his bedpost every night. The simple visual image of hanging up the instrument is strongly and tragically evocative in a Biblical context. In the Hebrew Bible, the locus classicus is Ps. 137: "(1) By the rivers of Babylon, there we sat, and cried, when we remembered Zion. (2) On the willows in its midst we hung our lyres (kinnorōteinū). (3) For there they asked us - our captors - for the words of song; and our tormentors - for pleasure. (4) How shall we sing the song of the Lord on alien soil? (5) If I forget you, 0 Jerusalem, let my right hand wither: (6) Let my tongue cleave to the roof of my mouth if I do not remember you, if I do not raise Jerusalem above my chiefest joy." Surely this archetypal lament will echo in some way in any later evocation of a hanging lyre. But let us hear the story of David's nights, from the Babylonian Talmud.

\section{King David and Hermes' harp.}

A meandering discussion in Tractate $B$. Berakhot $3 \mathrm{~b}$ of how many watches there are in the night, touches upon the long abecedarian Psalm in which King David declares: "At midnight (hașōt laylāh) I will rise to give You thanks for the judgments of Your righteousness" (Ps. 119.62). The text then asks whether David indeed arose at midnight and goes on to describe his activities upon waking. But it is first objected that he was already awake in the evening, so how could he be asleep, in order to rise? (The logic is a bit like that of the Mad Hatter's tea party in the English mathematician Lewis Carroll's novel, ostensibly for children: When Alice in Wonderland is offered another cup of tea, she ruefully observes that it is impossible to take one, since she has not yet been poured a first cup.) R. Ze'īrā solves the dilemma by offering a compromise solution: 'ad hașōt laylāh hāyāh mitnamnēm kesūs "till midnight he would doze like a horse". This is to be understood as a light sleep: horses most often rest thus, standing on four feet, rather than sprawling whenever they sleep as, for instance, cats do. ${ }^{32}$ R. Ašì adds, 'ad hașōt laylāh hāyāh 'ōsēq be-divrēi Tōrāh, mi-kān ve-ēilākh be-šìrōt ve-tišbāḥōt "till midnight he would occupy himself with the words of Torah; thenceforth, with songs and praises." So in a way David did not really sleep at all the way other men do. But the conversation returns to the initial question: How did David know when it was exactly midnight?

R. Ahā b. Bīznā comes to the point, echoing the tale of Hermes and the lyre. He said (in the name of) Šim ōn Hasīdā, Dāvid sìmānā havā lēih de-āmar rav aḥa bar bīznā āmar šim'ōn hasīdā kinnōr hāyāh tālūi le-ma'lāh mim-mițtātō šel dāvid vekhēivān še-higīa hașōt laylāh bā rūah șefōnīt ve-nōševet bō ū-menaggēn mēéēāv miyyād hāyāh 'ōmēd ve-'ōsēq ba-Tōrāh 'ad še-'ālāh 'ammūd haš-šahar “... a lyre was hanging over David's bed and as midnight arrived the north wind would come and

\footnotetext{
32 One offers for this observation not a printed source (one tome delivering another, as in the horrid scene of arid academic fertility depicted by Orozco in his fresco in a dining hall at Dartmouth college) but that most elusive kind of learning in modernity, direct experience- a life lived in the good company of both horses and cats. Horses will stretch themselves out on their sides only in deep sleep or if they are, God forbid, very ill.
} 
would blow through it and play over it: at once he would stand and busy himself with Torah until the break of the dawn." So music played by the wind/spirit would waken the king who by playing his lyre and praising God would then himself waken the very dawn. After this pre-dawn Torah study, as morning came, the sages of the nation would enter into the presence of the king and remind him: Israel needs sustenance (parnāsāh). So then presumably David would leave his study of Divine Scripture for a time (both the Law and the Psalms, before midnight and after it, qualifying as Torah) to attend to the needs of his people. We shall see presently that this order of nocturnal activities parallels, the schedule according to which the Lord divides His own day.

There are four winds, and each blows for six hours of the day, in this order: East, South, West, and North. (R. Hai Gaon, cited by the Rashba, said there was a timer that made the harp face the north wind exactly at midnight, but this seems a superfluous explanation verging on the comic inventions of Rube Goldberg, as the lyre could easily be hung in the right cardinal direction and, alarm clock or no, Boreas still had to be punctual. Indeed, Rashi explains the matter that way: David's lyre was positioned to catch the north wind when it blew, and it blew on time. ${ }^{33}$ ) And how do we know it was a lyre that woke David? R. Yiṣhaq b. Addā and others cite by way of a source Ps. 57.9, where David declares, 'ürāh khvōdī 'ūrāh han-nēvel ve-khinnōr à'îrāh šāḥār, "Wake, 0 my glory [i.e., heart, soul], wake, psalter and lyreI shall awaken the dawn." 34 The verse does not, to be sure, tell us precisely that the lyre woke David. It is more a justification, one thinks, for the co-optation of the Greek story. The Gemara tells us David would then address God (B. Berakhot 4a): ribbōnō šel 'ōlām lo hasīid anī še-kol malkhēi mizraḥ ù-ma'arāv yešēnīm 'ad šāloš šāōot va-ani hașōt laylāh āqūm le-hōdōt lākh, "Master of the Universe, am I not pious? For all the kings of west and east sleep till the third hour and I at midnight will arise to render thanks to You." Why was he so anxious? He knew he had sinned lustfully; so his music was offered in expiation.

There is a variant of this mythological tale in the discussion in Midrash Tanhūmā of the parashah- weekly Torah portion-Be-ha'alötkhä (Bamidbar/Numbers chs. 8-12), which discusses inter alia the musical instruments and other implements to be made for the Mishkan - the Tabernacle, precursor of the Temple. The text comments on the verse "Make for yourself two trumpets" that the two in the Temple were hidden or deposited in the treasury (af ha-ḥașoșrōt še-hāyū vam-miqdāš

\footnotetext{
${ }^{33}$ Davis 2006, p. 226 n. 8.

${ }^{34}$ In medieval Armenia the guards of the last watch of the night at the fortress of Hromkla, the residence of the Catholicos (Supreme Patriarch of the Armenian Church) St. Nersēs Šnorhali ("the Graceful", an ecclesiastical-academic title) used to greet the welcome rays of dawn with a preChristian hymn to the sun, a divinity of Zoroastrianism. Hearing these, he chose this verse of the Psalm, in its literal translation "Wake, 0 my glory!" as a proper Christian hymn to greet the morning, Zart'ik' p'ar'k'im. The word for glory in Armenian is itself a loan from a form of Old Iranian farnah-, the Divine sun-like glory bestowed upon heroes and kings. St. Nersēs often co-opted such Zoroastrian imagery, often more explicit, in his religious songs to reach out to the still-unconverted Children of the Sun of his nation.
} 
nignezū); therefore, it seems, David used to use (mištamēs) a lyre instead. ${ }^{35}$ There follows the story in B. Berakhot, but with an addition at the end: when the north wind blew through it, David would arise instantly ve-khol hat-talmīdìm ve-hāyū 'ósqīn ba-Tōrāh 'ad 'amūd haš-šaḥar "and all the schoolchildren, and they would occupy themselves with Torah until the break of dawn." David would then explain, Derekh haš-šaḥar lihyōt m'örēr benēi ädām, avāl anī me'örēr et haš-šahar, "It is the way of the dawn to be the awakener of the children of Adam, but I am the awakener of the dawn." The midrash here adds to the story, introducing a subtle element of moral decision to what might otherwise be unseemly boasting: David's free will or inclination (yișrō; this may likely be an abbreviation for his evil inclination, yeșer ha$r a$ ) would ask him, "David, are you not a king? It is the way of kings to be sleeping till the third hour; and why do you stand at midnight?"36 So David would reply with the Psalmodic verse "Awake, my glory [literally rather than as a word for the heart and soul, cf. supra]" and explain, taking the meaning of kāvōd in its literal sense of "glory", èin kevōdkhā lifnēi kevōd yoșerkhā klūm, "your glory is nothing before the glory of your Maker." 37 David's retort may contain a play on the root $y$-s-r and address also thereby the distinction and potential conflict we noted earlier between human free will and artifice, and the (evil) inclination to which they are vulnerable (yeșer) vs. divine inspiration and action - the work of the Maker (Yōṣer). He would seem here to resolve the problem by suggesting one has the power to control one's inclination towards vice, including here the vice of sloth.

The detail of schoolchildren (students? disciples?) is not in the Gemara, but one suspects it was drawn in the midrash from the famous and charming discussion in the Talmud, B. 'Avodah Zarah 3b, about how the holy One, blessed be He, spends His day, since the description of David's night in the Gemara already corresponds, grosso modo, to it: R. Yehudah reports that Rav said the day is 12 hours long. During the first three He studies Torah. During the next three He sits in judgment on the world, and when He sees it is guilty enough to deserve destruction, He moves from the seat of justice to the seat of mercy. During the third part of the day He feeds the whole world. During the fourth part He plays with the sea monster Leviathan (cf. Ps. 104.26). But another authority differs, insisting God has not laughed since the destruction of the Temple, and insists instead that now He yōšêv ü-melammēd tīnōqōt šel bēit rabbān tōrāh "sits and teaches Torah to little children from rabbinical houses" (on babes as pupils, citing Isaiah 28.9). God's action in the third

\footnotetext{
${ }^{35}$ Since David's son Solomon was to build the Temple, the reference to it in the midrash seems an anachronism. See Russell 2005.

36 The sages who set down the Babylonian Talmud lived in Parthian and Sasanian Mesopotamia; so their discussions are steeped in knowledge of, and direct or oblique references to, the Zoroastrian state religion of the Iranians. There may be one such reference in David's resistance to the inclination to sleep late. Zoroastrians were in oldest times mostly rural folk, herders and farmers, for whom it was virtue to rise at cock-crow (the rooster, thus, is holy) and vice to lave a lie-in. So there was a demoness of sloth, Bušyąstā, whose name was originally an optative form of "to be" meaning "let it be (later)". This verb turned temptress would whisper to sleepers her infernal tune of "Let It Be", encouraging them not to get out of bed yet. It is an anti-alarm clock we all know. In Judeo-Persian she is de-demonized to bušāsf, an innocuous siesta.

37 Davis 2006, pp. 226-227 with Hebrew text and English rendering; all translations here are mine.
} 
part of the day- nourishing the whole world - resonates with the morning visit to court of the sages recounted in the Bavli to ask king David to give sustenance to Israel. And one notes a correspondence, too, of the quadripartite Divine day and the four winds and four watches. ${ }^{38}$ It is difficult to assert the priority of a narrative in the correspondences and intertextualities of the Talmud, perhaps the world's first true hypertext. But it seems safe at least to suggest that in some ways the schedules and protocols of the court of the King of Kings of Kings (Who is thus one up on the Sasanian Persian šăhanšāh, who is merely "King of Kings") are to inform those of the royal court of His people Israel.

In the Torah portion that our Midrash comments upon, elaborating the story of David and his lyre from the Bavli, God also addresses Aaron and Miriam (Num. 12.68), telling them that He makes Himself known to a prophet in a vision (mar'eh), and speaks to him in a dream (halöm); but not so with Moses, with whom the Lord speaks mouth to mouth, plainly, and Moses beholds His likeness (temunāh). Though David is not Moses, and does not behold the Lord face to face, neither is he one who receives inspiration passively, in sleep: the assimilated topos of the Aeolian lyre of Hermes becomes here only a call to him to wake more fully from a light slumberand then, in full wakefulness, after midnight when other monarchs are still sound asleep, moved passively in the oceanic tide of dream, the alert and watchful King of Israel composes his songs of praise and, like the holy One, blessed be He, employs the fourth and final watch to teach Torah to children. On his lyre, the lyre of the Psalms, he does not play the devil's music - for he has overcome by his piety the blandishments of the evil inclination as the pagans cannot hope to do. The Amoraim have thus taken the popular story of Hermes' lyre and deployed it to the advantage of Israel. David acquired the lyre of Hermes and the image of Orpheus; with his psalmody and piety he has out-performed both Greeks.

Earlier one suggested that the mournful Psalmodic image of the lyres of the exiles hanging on willow branches by the rivers of Babylon- though chronologically long after David's reign, of course - must overshadow subsequent uses of the image when writers look in retrospect to the Biblical age. ${ }^{39}$ The Talmudic reader cannot have failed to compare the two: the seated exiles' silence and refusal vs. the rising David's greater, eager songs of praise. The Psalms are poetry, and a

\footnotetext{
38 There are four faces of the Divine merkabah-chariot, too; and Christians carried over this quadripartite symbolism into further elaborated commentary on the four-armed Cross. See Russell 1997.

39 The Chronicle of Yerahme'el senses the violence of the grief of the exiles: when their captors threatened to force them to play, the Children of Moses (benēi Mošeh) tore off their fingers with their own teeth. Then a cloud came, and lifted them, and took them beyond the river Sambatyon. See Reeves 2005, p. 211. On the goings-on beyond the mythical river that throws up stones all week long but rests on Shabbat, see Russell 2013 and 2014-2015. This essay began as a Shabbat stay at the hospitable home in Kiryat ha-Yovel, Jerusalem, with its well-stocked library, of my old friend and mentor Professor Michael Stone of the Hebrew University. He invited me to offer the Dvar Torah at his synagogue; as I leafed through Midrash Tanchuma on the week's portion, I realized I had heard of wind blowing through a lyre before, and one thought led to another. It is a pleasure to offer these lines to him.
} 
poet may understand them in ways a scholar is not trained by sensibility and inclination to do. So one defers to the comment on these passages of a friend in whose soul the spirit plays - the Israeli English-language poet Paul Raboff (private letter of 30 June 2017, Ein Kerem, Jerusalem). He writes: "Everything that David hanging his harp in Jerusalem is, the Jews hanging their harps by the river of Babylon isn't. Can we learn anything from the contrast? There the Shechina [the Divine Presence, which is believed to have dwelt in the Temple- JRR] is already homeless, dispersed, the kingdom shattered, lost with the Temple- all, all lost. They cannot sing, despondent, hang their harps, perhaps, a fugitive whisp [sic, combining perhaps wisp and whisper] of the wandering Shechina will yet pluck a muted remembrance of Jerusalem where the Shechina had nested, appeased by a penitent David (who had a lot to be penitent about) who hung his harp in the same room where he had spied Bathsheba and plotted. It would be a pure song, unmediated by any human hand, sinned, stained. The Shechina was close, intimate. It would speak to the besieged penitent directly. His enemies packed around himmen and demons. Words are the music of emotion; emotion, the music of principle; and dvar Elohim [the Word of God], three layered. The naked harp is our soul exposed to the ministrations of the Shechina, hanging unsupported by will power, human interference."

It has been suggested that the canonical Hebrew Bible has 24 books (Josephus mentions only 22) because the Rabbis knew each of the epic poems of Homer had 24. Codification was stimulated in part perhaps by competition, and also emulation. From the Ten Commandments (five on one stone, five on the other, like the fingers of two hands) to gematria, Torah learning is insightful exegesis and entrancing storytelling - and a numbers game. There are five books of the Chumash, the Pentateuch - the mind, law, and prose of God. When it came time to codify the Psalms, the Rabbis divided them accordingly into five books to correspond to the Chumash, as the heart, grace, and poetry of God's own sweet singer, His beloved David. Though the number here appealed to a precedent within the tradition, the Rabbis lived in a world where they also heard the sound from outside, heard the myth of Hermes and turned it around, to answer unasked but anxious questions, to affirm the truth of the faith, to embroider the rich career of their own great lyricist. One can answer, when it comes to unpacking a Talmudic tale, Tertullian's tendentious question, "What has Athens to do with Jerusalem?" When it comes to music, everything. ${ }^{40}$

\footnotetext{
40 One hesitates to combine the sublime with the ridiculous; but it must be observed parenthetically that some elements in Western culture have co-opted David in a vulgarly Hellenizing direction that masks an unmistakable and dark bias. I do not mean Michelangelo's statue. In 1974, Thomas Burnett Swann published a science-fiction/fantasy novel about David and Jonathan entitled, unsurprisingly, How Are The Mighty Fallen. Swann populates his homoerotic reverie with pagan fairies, satyrs, leprechauns, mermaids, chimaeras, and so on; and Jonathan is made to sport a pair of atrophied wings. The author portrays the prophet Samuel as a batrachian creature, a squat, bug-eyed, fat religious fanatic serving a monstrous god (that is, God). The Philistines (scil., gentiles, Aryans) are a gentle, highly civilized people without a bone of cruelty in their svelte bodies. The Israelites are presented as scrappy savages whose various battles are part of one continuous war of expansion and
} 


\section{Bibliography.}

John Block Boardman, Orpheus in the Middle Ages, Cambridge, MA: Harvard University Press, 1970.

James H. Charlesworth, ed. and tr., The Odes of Solomon, Oxford: Oxford University Press, 1973.

Rabbi Avrohom David, general editor; Reb S. Kassel, translator and annotator, The Metsudah Midrash Tanchuma, Bamidbar I (Midraš Tanḥūmā, Bamidbar-Šelaḥ), Lakewood, NJ: Israel Book Shop, 2006.

J. Massingberd Ford, "Was Montanism a Jewish-Christian Heresy?" Journal of Ecclesiastical History 17.2, October 1966, pp. 145-158.

Robert Graves, The Greek Myths, New York: Braziller, 1957.

Tomas Hägg, "Hermes and the invention of the lyre: an unorthodox version," Symbolae Osloenses 64, 1989, pp. 36-73.

Michael Lattke, Odes of Solomon: A Commentary, Minneapolis: Fortress, 2009.

Saul Lieberman, Hellenism in Jewish Palestine, New York: Jewish Theological Seminary, 1950.

Jack Lindsay, The Ancient World: Manners and Morals, New York: G.P. Putnam's Sons, 1968.

Thomas F. Mathews, The Clash of Gods: A Reinterpretation of Early Christian Art, Princeton: Princeton University Press, 1993.

John C. Reeves, Trajectories in Jewish Apocalyptic: A Postrabbinic Jewish Apocalyptic Reader, Atlanta: Society of Biblical Literature, 2005.

James R. Russell, "Vec' hazareak mateana Hayoc' mej" ("The Book of the Six Thousand in Armenia"), Armenian version published in Banber Erevani Hamalsarani, Erevan, Armenian SSR; expanded English version: "The Book of the Six

conquest. Jonathan himself is blond and blue eyed. Spunky little red-haired David is blue eyed as well. David ambles around the Israelite camp, dodging the lewd advances of hairy Jews and occasionally announcing, rather like a folksy singer-songwriter avant la lettre, "I'm writing a new psalm." He composes Psalm 23 (not numbered in the text but easy to identify, shall we say) in honor of Jonathan, to cheer him up after Jonathan's faithful armor bearer is immolated as yet another human sacrifice to God by the sanguinary Samuel. Enough! Mr. Swann, this is your song. How are the mighty fallen, indeed. 
Thousand: An Armenian Magical Text," Bazmavēp 147.1-4, Venice, 1989, pp. 221243.

James R. Russell, "The Four Elements and the Cross in Armenian Spirituality, with an Excursus on the Descent in Merkavah Mysticism," Jewish Studies Quarterly, Tübingen, Vol. 4.4, 1997, pp. 357-379.

James R. Russell, “The Epic of the Pearl," Revue des Études Arméniennes 28, 20012002, pp. 29-100.

James R. Russell, Armenian and Iranian Studies, Armenian Heritage Press and Harvard Armenian Texts and Studies 9, Cambridge, MA, 2004.

James R. Russell, "The Credal Poem Hawatov xostovanim ("I confess in faith") of St. Nerses the Graceful," in J.J. van Ginkel et al., eds., Redefining Christian Identity: Cultural Interaction in the Middle East since the Rise of Islam, Orientalia Lovanensia Analecta 134, Leuven, 2005, pp. 185-236.

James R. Russell, "Hārūt and Mārūt: The Armenian Zoroastrian Demonic Twins in the Qur'ān Who Invented Fiction," in S. Tokhtasev and P. Luria, eds., Commentationes Iranicae: Sbornik statei k 90-letiyu V.A. Livshitsa, St. Petersburg: Institute of Oriental Manuscripts of the Russian Academy of Sciences and Nestor-Historia, 2013, pp. 469480.

James R. Russell, "An Armenian Spirit of Time and Place: the Švot," Revue des Etudes Arméniennes 36 (2014-2015), pp. 13-59.

Edith B. Thomas, King David Leaping and Dancing: A Jewish marble from the Roman Imperial period, Budapest: Akadémiai Kiadó, 1970.

Bo Utas, "The invention of the barbat according to 'Unsuri's Vamiq-u-'Adhra," H.R. Roemer and I. Afshar, eds., Sokhanvari: 55 papers in memory of Parviz Natel Khanlari, Tehran, 1997, pp. 145-152, repr. in C. Jahani and D. Kargar, eds., Manuscript, Text, and Literature: Collected Essays on Middle and New Persian Texts by Bo Utas, Wiesbaden: Ludwig Reichert, 2008, pp. 195-202.

Egon Wellesz, A History of Byzantine Music and Hymnography, $2^{\text {nd }}$ ed., Oxford: Oxford University Press, 1998.

M.L. West, The Orphic Poems, Oxford: Oxford University Press, 1983.

M.L. West, Ancient Greek Music, Oxford: Oxford University Press, 1992. 